\title{
THE EXPERIMENT ABOUT RECOVERABLE ANCHOR CABLE IN THE FOUNDATION PIT SUPPORT
}

\author{
Shimin ZHANG \& Shichen YU\& Yingsheng HUANG\& Miaomiao SUN
}

\author{
\&Xinquan WANG \\ Zhejiang University City College,Zhejiang, China
}

KEYWORD: recoverable anchor cable ;foundation pit support; resistance to plucking of anchor cable

\begin{abstract}
Using recoverable anchor cable is a good way to resolve problems about underground space occupation and waste of money. So the recoverable anchor cable applied in engineering has long and meaningful significance this treatise uses the resistance to plucking of anchor cable in the certain unit dismantling and settling building for example ,and it proves that recoverable anchor cable is applicable.
\end{abstract}

\section{Introduction}

With the incessant development of construction trade, for guaranteeing someone's safety, foundation ditch becomes more important in engineering. However, foundation ditch as a temporary structure changes from necessary to rubbish. And some supporting structure has to stay at underground, and it not only occupies a lot of the space underground, but also causes the waste of money. This passage refers to the recoverable anchor cable which can solve the problem mentioned before. At the same time, this passage uses the resistance to plucking of anchor cable to prove the feasibility and importance of the recoverable anchor cable.

\section{Project Overview}

The project is the second bid section of dismantling and settling house of the residents whose status are changed from rural to urban in one plot and the project is located in Jiubao Town, Jianggan District, Hangzhou City. The second basement area in the south of the foundation pit adopts cast-in-situ bored pile plus two recoverable anchor cables and cast-in-situ bored pile plus one reinforced concrete horizontal inner support bracket, beyond the pit, three-axis cement mixing pile is provided to stop water and the foundation pit security is level 1, and the recoverable anchor cable connecting method is shown in Figure 1, 2 and 3.

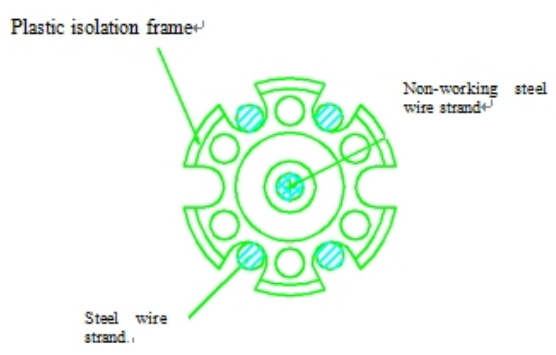

Figure 1. The structural drawing of recoverable anchor cable end 


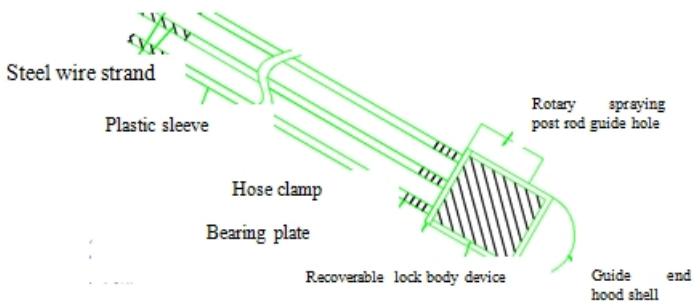

Figure 2. Anchor cable to bracket enlarged detail

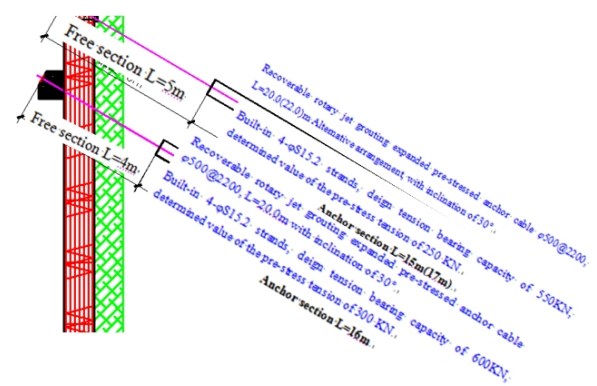

Figure 3. Anchor cable connection detailed diagram

The first basement area in the north of the foundation pit and the boundary area of the first floor underground and the second floor adopt soil nailing wall (shot anchoring net) bracket, the foundation pit security is level 2. The anchor cable construction is carried out following the principle of "by sections and floors, from top to bottom, anchoring first and excavation second", and the recoverable anchor cable construction process is shown in Figure 4.

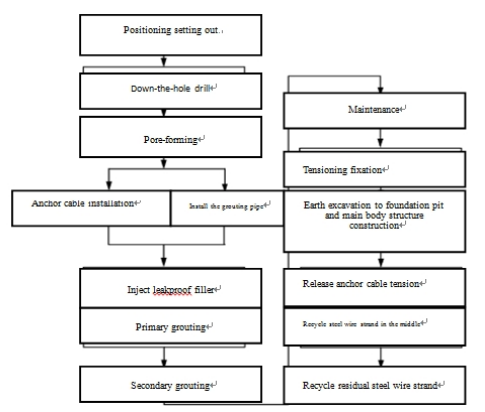

Figure 4. Recoverable anchor cable construction process flow chart

The three anchor cables in the test are test anchor cables with a total length of $20 \mathrm{~m}$ and the whole length as free section, 4 bundles of $\Phi 15.2$ pre-stressed steel wire strand are built in the anchor cable and the design bearing pull-out capacity standard value is $700 \mathrm{kN}$. 


\section{Geological Conditions}

Foundation soil physical mechanics parameter list

Table 1 Foundation soil physical mechanics parameter list

\begin{tabular}{|c|c|c|c|c|c|c|c|c|}
\hline \multirow{4}{*}{$\begin{array}{l}\text { Soil } \\
\text { layer } \\
\text { number }\end{array}$} & \multirow{4}{*}{ Soil layer name } & \multicolumn{2}{|c|}{ Natural foundation } & \multicolumn{2}{|c|}{ Pre-stressed pipe pile } & \multicolumn{2}{|c|}{ Cast-in-situ bored pile } & \multirow[b]{2}{*}{$\begin{array}{l}\text { Pile } \\
\text { periphery } \\
\text { soil pull-out } \\
\text { bearing } \\
\text { capacity } \\
\text { factor }\end{array}$} \\
\hline & & $\begin{array}{l}\text { Foundation } \\
\text { soil bearing } \\
\text { capacity } \\
\text { characteristi- } \\
\text { c value } \\
\end{array}$ & $\begin{array}{l}\text { Compressi } \\
\text {-on } \\
\text { modulus }\end{array}$ & $\begin{array}{l}\text { Side } \\
\text { resistance } \\
\text { characteris } \\
\text {-tic value }\end{array}$ & $\begin{array}{l}\text { End } \\
\text { resistance } \\
\text { characterist } \\
\text {-ic value }\end{array}$ & $\begin{array}{l}\text { Side } \\
\text { resistance } \\
\text { characteris } \\
\text {-tic value }\end{array}$ & $\begin{array}{l}\text { End } \\
\text { resistance } \\
\text { characteris } \\
\text {-tic value }\end{array}$ & \\
\hline & & fak & Es1-2 & qsia & qpa & qsia & qpa & $\lambda$ \\
\hline & & $\mathrm{kPa}$ & $\mathrm{MPa}$ & $\mathrm{kPa}$ & $\mathrm{kPa}$ & $\mathrm{kPa}$ & $\mathrm{kPa}$ & - \\
\hline (1) & Clayey silt & 85 & 5.5 & 10 & & 8 & & 0.60 \\
\hline (2) & Muddy silt clay & 75 & 3.2 & 11 & & 10 & & 0.75 \\
\hline (3) & Silt & 180 & 9.0 & 32 & 1400 & 28 & & 0.60 \\
\hline (4) & Clay silt & 150 & 6.0 & 32 & 700 & 29 & & 0.75 \\
\hline (5) & Silt & 220 & 12.0 & 30 & & 28 & & 0.60 \\
\hline (6) & $\begin{array}{l}\text { Completely } \\
\text { weathered } \\
\text { argillaceous siltstone }\end{array}$ & 180 & 10.0 & & & 38 & & 0.70 \\
\hline
\end{tabular}

\section{Inspection}

\section{Inspection equipment}

$100 \mathrm{t}$ centre hole jack, straight steel ruler, dial indicator, etc.

\section{Inspection method}

The test obtains the conclusion with multi-cycle loading method in basic test method through load-displacement figure analysis and diagram analysis. The loading grade and anchor head displacement observation time can be seen in Table 2 .

Table 2 Multi-cycle loading test loading grading and anchor head displacement observation time

\begin{tabular}{|l|l|l|l|l|l|l|l|}
\hline \multirow{2}{*}{$\begin{array}{l}\text { Cycle } \\
\text { times }\end{array}$} & \multicolumn{6}{l}{ Ratio of grading load and maximum test load (\%) } \\
\cline { 2 - 8 } & Initial load & Loading process & \multicolumn{4}{l|}{ Unloading process } \\
\hline First cycle & 10 & 20 & 40 & 50 & 40 & 20 & 10 \\
\hline $\begin{array}{l}\text { Second } \\
\text { cycle }\end{array}$ & 10 & 30 & 50 & 60 & 50 & 30 & 10 \\
\hline Third cycle & 10 & 40 & 60 & 70 & 60 & 40 & 10 \\
\hline $\begin{array}{l}\text { Fourth } \\
\text { cycle }\end{array}$ & 10 & 50 & 70 & 80 & 70 & 50 & 10 \\
\hline Fifth cycle & 10 & 60 & 80 & 90 & 80 & 60 & 10 \\
\hline Sixth cycle & 10 & 70 & 90 & 100 & 90 & 70 & 10 \\
\hline Observation time(min) & 5 & 5 & 10 & 5 & 5 & 5 \\
\hline
\end{tabular}

\section{Reading time and discriminating stability standard:}

(1)Under initial loads, the anchor head displacement reference value is measured for 3 times, when the degrees every $5 \mathrm{~min}$ are same, it can be the anchor head displacement reference value.

(2)After each grade loading and unloading is stable, anchor head displacement is measured for no less than 3 times within the observation time.

(3)When the anchor head displacement increment is not more than $0.1 \mathrm{~mm}$, the next grade load can be applied within each grade load observation time.

(4)After loading to the maximum test load, when the terminating loading conditions are not reached, the next grade loading can be carried out continuously. 


\section{Conditions of terminating loading:}

(1)The anchor head displacement increment generated from the later grade load is larger than 5 times of the anchor cable displacement increment generated from the last grade load under unit load;

(2)Anchor head displacement is not constricted;

(3)Anchor rod body is broken.

\section{Result determination:}

(1)The ultimate pull-out bearing capacity of single anchor cable shall take the last load value of terminating load when the terminating loading conditions are occurred under one grade test load; when they are not occurred, it shall be take the maximum test load value.

(2)For the test anchor cable participating in the statistics, when the ultimate pull-out bearing capacity range is not more than $30 \%$ of its average value, the anchor cable ultimate pull-out bearing capacity standard value can take the average value; when the range is more than $30 \%$ of the average value, the test anchor cable number should be added appropriately and the anchor cable ultimate pull-out bearing capacity standard value should be determined after re-statistics based on the actual situations according to the cause of too large range.

\section{Test Result Analysis}

The ultimate bearing capacity conclusion results of three anchor cables obtained from the anchor cable pull-out test can be seen in Table 3 and its corresponding load- displacement curve, load- elastic displacement-plastic displacement curve can be seen in Figure 5-10.

Table 3 Anchor cable pull-out test results summary table

\begin{tabular}{|l|l|l|l|l|l|l|l|}
\hline & & & \multicolumn{2}{|l|}{ Cyclic loading } & Final loading & \\
\cline { 4 - 7 } No. & $\begin{array}{l}\text { Anchor } \\
\text { cable } \\
\text { number }\end{array}$ & Test date & $\begin{array}{l}\text { Maximum } \\
\text { test load } \\
(\mathrm{kN})\end{array}$ & $\begin{array}{l}\text { lumulative } \\
\text { displaceme } \\
\text { nt volume } \\
(\mathrm{mm})\end{array}$ & $\begin{array}{l}\text { Maximum } \\
\text { test load } \\
(\mathrm{kN})\end{array}$ & $\begin{array}{l}\text { Cumulative } \\
\text { displaceme } \\
\text { nt volume } \\
(\mathrm{mm})\end{array}$ & $\begin{array}{l}\text { Ultimate } \\
\text { bearing } \\
\text { capacity }\end{array}$ \\
\hline 1 & S1\# & 2015.3 .16 & 700 & 99 & 840 & 123.4 & $\geq 840 \mathrm{kN}$ \\
\hline 2 & S2\# & 2015.3 .17 & 600 & 10.99 & $/$ & $/$ & $\geq 600 \mathrm{kN}$ \\
\hline 3 & S3\# & 2015.3 .18 & 500 & 82.8 & 660 & 115.4 & $\geq 660 \mathrm{kN}$ \\
\hline
\end{tabular}

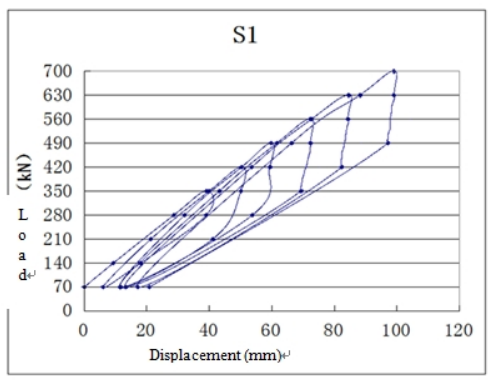

Figure 5. S1\#Load - displacement curve 


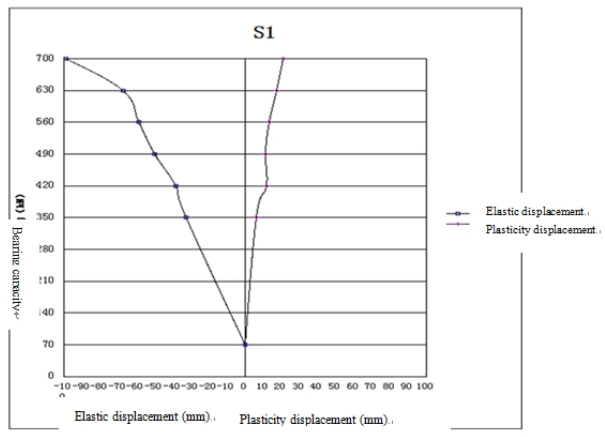

Figure 6. S1\# Load - elastic displacement - plasticity displacement curve

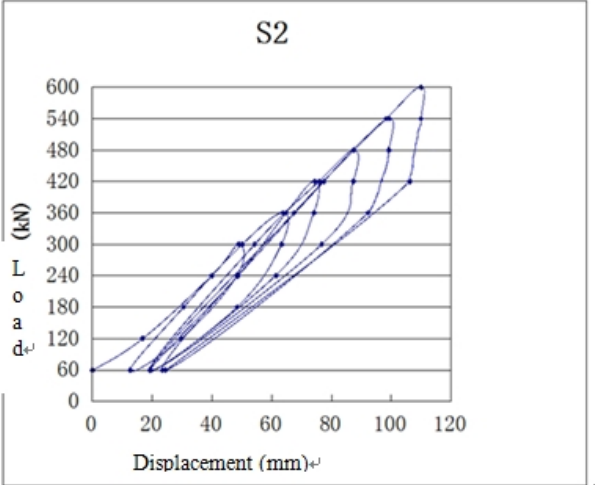

Figure 7. S2\# Load - displacement curve

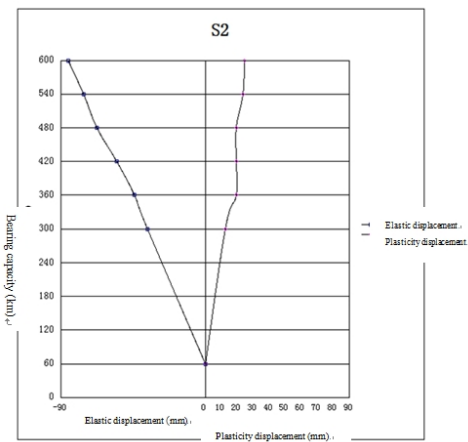

Figure 8. S2\# Load - elastic displacement - plasticity displacement curve

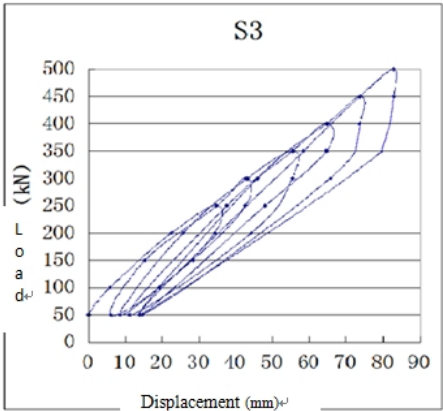

Figure 9. S3\# Load - displacement curve 


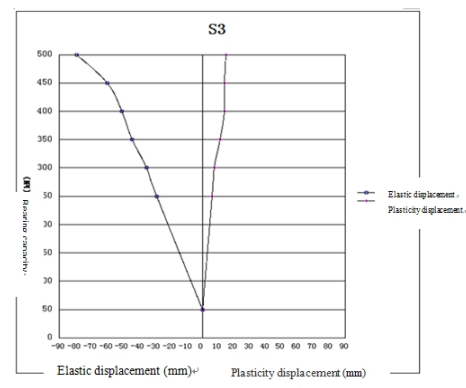

Fig. 10 S3\# Load - elastic displacement - plasticity displacement curve

It can be seen from the figure:

S1 \# test anchor cable is graded according to $700 \mathrm{kN}$ pull-out bearing capacity standard values and not broken within six-cycle loading scope, in order to test the anchor cable ultimate bearing capacity, the load is continuously loaded to $840 \mathrm{kN}$, but the anchor cable is still not broken.

According to the anchor cable test site coordination meeting, considering the anchor cable may not be recycled for deformation on the anchor cable end because of too large loading value, S2\# and S3 \# test anchor cable is loaded circularly by grades according to $600 \mathrm{kN}$ and $500 \mathrm{kN}$ loads required by the design unit.

$\mathrm{S} 2$ \# anchor cable is not broken under $600 \mathrm{kN}$ grading cyclic loading condition.

S3\# anchor cable is not broken under $500 \mathrm{kN}$ grading cyclic loading condition and is still not broken after finally loading to $660 \mathrm{kN}$.

\section{Conclusion}

(1) The recoverable anchor cable, which can not only reduce underground space resource occupancy, but also facilitate the cost recycling and saving, is one of the important methods for foundation pit bracket.

(2)The recoverable anchor cable displacement linearly varies with the multi-cycle loading of the tensile stress approximately and it is of very obvious laws.

(3)Through on-site project inspection, the recoverable anchor cable has a certain pull-out effect, which can be sufficient to provide the project with the required resistance to ensure its safety.

\section{ACKNOWLEDGEMENT}

The work is fully supported by Science Technology Department of Zhejiang Province(2013C31041), and Ministry of Housing and Urban-Rural of Zhejiang Province (2014Z099), and Zhejiang University City College (J-15017), and zhejiang university city college of Research project for College Students（XZ2015524077）.

\section{References}

[1] LI Zhaoping,HUANG Mingli,WANG Jian.LI Wentao. Study on the Recoverable Anchor Cable Supporting Scheme Optimization Design for Metro Foundation pit[J] Chinese Journal of Underground Space and Engineering 2012.8

[2] Wang Dongxin. Construction Technology of Recoverable Anchor Cable in Deep Foundation Pit[J] geotechnical engineering

[3] ZHAO Qijia,LIU Zhenggen. Application of recycling anchor cables in support of excavations[J] Journal of Rock Mechanics and Geotechnical Engineering 2012 